\title{
Adenovirus-mediated catalase gene transfer reduces oxidant stress in human, porcine and rat pancreatic islets
}

\author{
P.Y. Benhamou ${ }^{1}$, C. Moriscot ${ }^{2}$, M.J. Richard ${ }^{1}$, O. Beatrix ${ }^{2}$, L. Badet ${ }^{2}$, F. Pattou ${ }^{3}$, J. Kerr-Conte ${ }^{3}$, J. Chroboczek ${ }^{2}$, \\ P. Lemarchand ${ }^{4}$, S. Halimi ${ }^{1}$ \\ ${ }^{1}$ Department of Endocrinology, University Hospital, Grenoble, France \\ ${ }^{2}$ Institute of Structural Biology, Grenoble, France \\ ${ }^{3}$ Department of Surgery, University Hospital, Lille, France \\ ${ }^{4}$ INSERM U25, Necker School of Medicine, Paris, France
}

\begin{abstract}
Summary Susceptibility of pancreatic islets to oxidant stress may affect islet viability and contribute to primary non function of allo- or xenogenic grafts. We investigated the influence of overexpression of catalase (CAT) on the viability of human, porcine and rat islets, as well as INS-1 beta-cell line. Islets were transfected with a replication-deficient adenovirus vector containing human CAT cDNA under the control of the adenovirus major late promoter (AdCAT) or a vector containing no foreign gene (AdNull) and used as a control. Oxidant stress was induced $48 \mathrm{~h}$ later by xanthine oxidase-hypoxanthine (XO $25 \mathrm{mU} / \mathrm{ml}, \mathrm{HX} 0.5 \mathrm{mmol} / \mathrm{l}$ ) or hydrogen peroxide $(100$ or $250 \mu \mathrm{mol} / \mathrm{l})$. Islet cell viability was assessed $72 \mathrm{~h}$ after CAT transfer by 4-[3-(4-Idophenyl)-2-(4 nitrophenyl)-2H-5-tetrazolio]-1,2, benzene disulphonate (WST-1) test. Baseline catalase activity was three to fourfold lower in porcine than in human islets. CAT activity was reproducibly increased 2.5to 7-fold in AdCAT infected islets, at least for
\end{abstract}

13 days. Overall, AdCAT conferred on human and pig islets a protection of $26.1 \pm 6.1$ and $21.2 \pm 9.8 \%$ on XOHX injury and $35.4 \pm 4.2$ and $57.9 \pm 10.5 \%$ on $\mathrm{H}_{2} \mathrm{O}_{2}$ stress. Similarly, rat islet cells and INS-1 cells were protected on XOHX stress by $17.8 \pm 2.3$ and $30.8 \pm 8.7 \%$, respectively. AdNull had no effect. Basal and stimulated insulin secretion was preserved in AdCAT-transfected human islets despite a XOHX challenge. This study validates adenovirus-mediated catalase gene transfer as a realistic approach to reduce non specific inflammation effects on human or porcine islet grafts. Moreover the relevance of defense mechanisms, previously suggested in human islets, is here illustrated in porcine islets. [Diabetologia (1998) 41: 1093-1100]

Keywords Islet transplantation, porcine xenograft, catalase, oxidant stress, superoxide dismutase, reactive oxygen species, adenovirus, gene transfer.
Received: 4 November 1997 and in revised form: 17 March 1998

Corresponding author: Dr P. Y. Benhamou, Department of Endocrinology, CHU, BP 217X, 38043 Grenoble, France

Abbreviations: CAT, catalase; HX, hypoxanthine; MOI, multiplicity of infection; ROS, reactive oxygen species; SOD, superoxide dismutase; XO, xanthine oxidase; IEQ, equivalent number if islets; AdCAT, adenovirus AdCAT, adenovirus containing catalase gene; $\mathrm{CV}$, coefficient of variation; AdNull, vector containing no foreign gene; OD, optical density; MTT, 3-[4,5dimethylthiazol-2-yl]-2,5-diphenyl tetrazolium bromide; WST-1, 4-[3-(4-Iodophenyl)-2-(4-nitrophenyl)-2H-5-tetrazolio]-1,3-benzene disulphonate; IFN $\gamma$, interferon gamma; TNF- $\alpha$, tumour necrosis factor-alpha.
The vulnerability of pancreatic beta cells to the cytotoxicity induced by reactive oxygen species (ROS) and nitric oxide has been largely documented [1-3]. The deleterious role of oxygen and nitrogen radicals contributes to both spontaneous autoimmune diabetes [4-7] and failure of islet transplantation [8]. This susceptibility is generally attributed to the relatively low levels of antioxidant enzymes in pancreatic islets [9-10]. There are, however, major differences between rodents and humans in both scavenger enzyme expression and susceptibility to beta-cell injury. $\mathrm{Hu}$ man beta cells were found to express higher levels of superoxide dismutase and catalase [11] and to be more resistant than rodent cells to sodium nitroprusside, streptozotocin or alloxan [12]. In this respect, lit- 
tle is known about porcine beta cells which are likely to be used in future xenotransplantation trials in humans. The role of oxygen free radicals in beta-cell destruction is also supported by studies of the protective effects of antioxidants against cytokine- or ROS-mediated beta-cell destruction [13]. These studies were conducted mostly in vitro and usually did not use genetic approaches, with the exception of the report of transgenic expression of $\mathrm{CuZn}$ superoxide dismutase in mice that enhanced the tolerance of pancreatic beta cells to two models of oxidative stress-induced diabetogenesis, alloxan- and streptozotocin-induced diabetes [14]. The application of these findings to the field of islet transplantation requires a feasible approach aiming at increasing repair or defense mechanisms of beta cells with a stable, simple and non-toxic method. Adenovirus vectors can transfer genes into pancreatic islets very efficiently [15-16]. In this study, using an adenoviral vector coding for human catalase, we report that a partial protection against the cytotoxic effects of oxygen free radicals can be conferred on human islets. We also show that porcine islets express lower concentrations of free radical scavenging enzymes than human islets and show that they can also be partially protected against ROS by adenoviral-mediated catalase gene transfer.

\section{Material and methods}

Pancreatic human, porcine and rat islets. Human pancreases were obtained from brain-dead donors during multiple organ procurement procedures and islets were isolated as described previously [17]. Briefly, islets were isolated by ductal distension of the organs and digestion of the tissue with collagenase $\mathrm{P}$ (Boehringer Mannheim, Indianapolis, Ind., USA) followed by a Euro-Ficoll density-gradient centrifugation using a COBE cell processor (Denver, Colo., USA). Islets were cultured in plastic Petri dishes at $37^{\circ} \mathrm{C}$ in $95 \%$ air and $5 \% \mathrm{CO}_{2}$. Culture medium contained $10 \%$ fetal bovine serum (FBS), $25 \mathrm{mmol} / \mathrm{l} \mathrm{N}-2$ hydroxyethylpiperazine-N-2-ethanesulphonic acid (HEPES), $24 \mathrm{mmol} / \mathrm{l}$ sodium bicarbonate, and antimycotic-antibiotic solution. Islet number was determined on a sample after dithizone staining and expressed as equivalent number of islets (IEQ: number of islets if all were $150 \mu \mathrm{m}$ in diameter). Islet viability was assessed by vital staining using fluorescent probes [17] and functionality as described below. Preparations used in this study $(n=4)$ exhibited over $90 \%$ purity and viability and an average yield of $2598 \pm 606$ IEQ/ g. A similar procedure was used for the isolation of porcine pancreatic islets from adult farm pigs, with $90 \%$ purity and an average yield of $3140 \pm 316 \mathrm{IEQ} / \mathrm{g}$ ( $n=6$ preparations). Inbred Wistar rat islets (Iffa-Credo, L'Arbresle, France) were also isolated by ductal injection of a collagenase solution followed by a purification on a Ficoll density gradient and were dissociated into single cells by trypsin as described previously [18]. Culture medium was CMRL 1066 for human islets, Ham's F12 for porcine islets and RPMI 1640 for rat islets [19]. Additional experiments were conducted on rat insulinoma cell line INS-1 (courtesy of W.P. Pralong, Lausanne, Switzerland), that were cultured in RPMI 1640 medium as described previously [20].
Adenoviral vectors. We used a E1-deleted, replication-deficient recombinant adenovirus containing human catalase cDNA under the control of adenovirus major late promoter (AdCAT) constructed as described previously [21]. A negative control consisted of a similar adenovirus containing no cDNA (AdNull). The recombinant adenovirus were propagated in 293 cells and were purified by $\mathrm{CsCl}$ density purification. The preparations were dialysed and stored in the dialysis buffer (10 mmol/l Tris-Cl pH 7.8, $15 \mathrm{mmol} / \mathrm{l} \mathrm{NaCl}, 10 \mathrm{mmol} / \mathrm{l} \mathrm{MgCl} 2$, $10 \%$ glycerol) at $-70^{\circ} \mathrm{C}$ until use. The titre of each viral stock was determined by plaque assay on 293 cells and the titres consistently ranged between $1-2 \times 10^{11}$ plaque forming units (pfu)/ $\mathrm{ml}$. Absence of replication-competent particles in adenovirus preparations was checked by polymerase chain reaction using primers specific for the AdE1A region. The concentration of recombinant adenovirus was quantified also by optical absorbance and the ratio particles:pfu consistently ranged between 50 and 80 [22].

Transfection of islets. Islets in suspension in 50-ml polypropylene tubes were washed once with culture medium and resuspended at a concentration of 4000 IEQ in $0.5 \mathrm{ml}$ culture medium. Adenovirus was added at a multiplicity of infection (MOI) of 25, except when stated and islets were incubated at $37^{\circ} \mathrm{C}$ in $95 \%$ air and $5 \% \mathrm{CO}_{2}$ for $1 \mathrm{~h}$, washed once with culture medium and cultured in multiwell plates. INS-1 cells were cultured in 96-well plates at an initial density of $3 \times 10^{4}$ cells per well for $24 \mathrm{~h}$, then exposed to adenovirus in $100 \mu \mathrm{l} \mathrm{cul-}$ ture medium at an MOI of 25 for $1 \mathrm{~h}$ and washed.

Antioxidant enzyme activities. Islets were pelleted by centrifugation and lysed by five freezing-thawing cycles in hypotonic $20 \mathrm{mmol} / \mathrm{l}$ Tris-HCl buffer. Metalloenzymes were determined in the supernatant obtained after centrifugation (10 $\mathrm{min}, 4000$ $\mathrm{g}, 4^{\circ} \mathrm{C}$ ) of the islet homogenate. Catalase activity was quantified according to the method of Aebi by following the disappearance of $\mathrm{H}_{2} \mathrm{O}_{2}$ in the presence of islet lysates supernatants as recorded spectrophotometrically at a wavelength of $240 \mathrm{~nm}$ [23]. One unit of catalase activity was defined as $1 \mu \mathrm{mol} \mathrm{H}_{2} \mathrm{O}_{2}$ consumed per min. Total superoxide dismutase activity (MnSOD and CuZnSOD) was determined by monitoring the auto-oxidation of pyrogallol according to the procedure of Marklund and Marklund [24]. One unit of SOD activity was defined as the amount of enzyme required to inhibit the rate of pyrogallol auto-oxidation by $50 \%$. The specific $\mathrm{CuZnSOD}$ inhibition by $\mathrm{KCN}$ ( $9 \mathrm{mmol} / \mathrm{l}$ final concentration) allows the MnSOD determination in the same conditions. All results were expressed relative to islet lysate protein content. Data were established from triplicate samples and from a minimum of three different batches of islets to control for inter-individual variability.

Oxidative stress. Xanthine oxidase (XO, grade III from buttermilk) and hypoxanthine (HX, 6-hydroxypurine), obtained from Sigma (St Louis, Mo., USA) were dissolved freshly before use in the appropriate culture medium for the islet species. These reagents were added to the wells containing islets (96-well plates, 20 islets per well) or islet single cells $\left(5 \times 10^{4}\right.$ cells per well) or INS-1 cells in $200 \mu \mathrm{l}$ at final concentrations of $0.5 \mathrm{mmol} / \mathrm{l} \mathrm{HX}$, with $\mathrm{XO}$ concentrations from 1 to $50 \mathrm{mU} /$ $\mathrm{ml}$. Control wells received medium, HX or XO alone. Concentration of hydrogen peroxide (Sigma) was checked at $240 \mathrm{~nm}$ shortly before use and it was distributed into the wells to achieve final concentrations ranging from $10-500 \mu \mathrm{mol} / \mathrm{l}$. In both oxidative challenges, islets or cells were stressed $48 \mathrm{~h}$ after transfection with AdCAT at MOI of 25 and then cultured for $16 \mathrm{~h}$ before viability tests. 
In vitro islet viability. Islet mitochondrial activity was assessed by a colorimetric assay derived and simplified from the more commonly known 3-[4,5-dimethylthiazol-2-yl]-2,5-diphenyltetrazolium bromide (MTT) test that was previously established as a valid method for islet viability assessment [25]. This assay was obtained from Boehringer Mannheim and is based on the cleavage of a tetrazolium salt 4-[3-(4-Iodophenyl)-2-(4-nitrophenyl)-2H-5-tetrazolio]-1,3-benzene disulfonate (WST-1) to formazan by the mitochondrial succinate-tetrazolium reductase. The formazan dye produced by viable cells is quantified in a multiwell spectrophotometre by measurement of the optical density (OD) at $440 \mathrm{~nm}$. Each experiment was conducted with a minimum of 6 wells per experimental group. Cytotoxicity of pro-oxidant agents and antioxidant activity of AdCAT (\% protection) were defined according to the following formula:

- cytotoxicity on control islets $\mathrm{C}=\left(\mathrm{OD}_{\mathrm{C}}-\mathrm{OD}_{\mathrm{CS}} / \mathrm{OD}_{\mathrm{C}}\right) \times 100$

where $\mathrm{OD}_{\mathrm{C}}=\mathrm{OD}$ of control islets and $\mathrm{OD}_{\mathrm{CS}}=\mathrm{OD}$ of control islets exposed to oxidative stress

- cytotoxicity on transfected islets $\mathrm{T}=\left(\mathrm{OD}_{\mathrm{T}}-\mathrm{OD}_{\mathrm{TS}} /\right.$ $\left.\mathrm{OD}_{\mathrm{T}}\right) \times 100$

where $\mathrm{OD}_{\mathrm{T}}=\mathrm{OD}$ of transfected islets and $\mathrm{OD}_{\mathrm{TS}}=\mathrm{OD}$ of transfected islets exposed to oxidative stress

- $\%$ protection $=(\mathrm{C}-\mathrm{T} / \mathrm{C}) \times 100$

In vitro islet functionality. Glucose-stimulated insulin secretion was determined by static incubation. Aliquots of 100 islets were plated in triplicate on $3 \mu \mathrm{m}$ Millicell inserts (Millipore, Bedford, Mass., USA) in a 12-well plate and consecutively stimulated for four different 1 -h periods in Krebs buffer containing $0.5 \%$ bovine serum albumin and $3.3 \mathrm{mmol} / 1$ glucose (period 1 and 2), $27.5 \mathrm{mmol} / 1$ glucose $+10 \mathrm{mmol} / \mathrm{l}$ theophylline (period 3), $3.3 \mathrm{mmol} / \mathrm{l}$ glucose (period 4). Medium samples were frozen at $-20^{\circ} \mathrm{C}$ for further insulin determination by RIA (CIS bio, Gif-sur-Yvette, France). A stimulation index was obtained as the ratio insulin released during period 3 per average of insulin released during period 2 and 4 .

Statistical analysis. Comparisons of enzymatic concentrations between species were performed with analysis of variance completed by Scheffe's $F$ test. The same test was applied for the comparisons of cytotoxicity levels between control, AdNull and AdCAT -treated islets. Data are shown as means \pm SEM.

\section{Results}

Baseline antioxidant enzyme activities. Activities were measured after overnight culture from triplicate samples of individual batches of islets. The inter-individual variability of catalase and SOD activities was assessed in different pancreases from the same species (human: $n=3$; porcine: $n=6$; rat: $n=5$ ). As shown in Figure 1, catalase activity was significantly higher in human islets $(9.1 \pm 2.4 \mathrm{U} / \mathrm{mg}$ protein, range $4.2-11.6$, coefficient of variation (CV) $46.4 \%$ ) than in porcine $(3.7 \pm 0.6 \mathrm{U} / \mathrm{mg}$, range $2.1-5.9$, CV $38.7 \%$, $p=0.02$ vs human) and rat islets $(1.3 \pm 0.2 \mathrm{U} / \mathrm{mg}$, range $0.7-1.9, \mathrm{CV} 42.3 \%, p=0.01$ vs human and

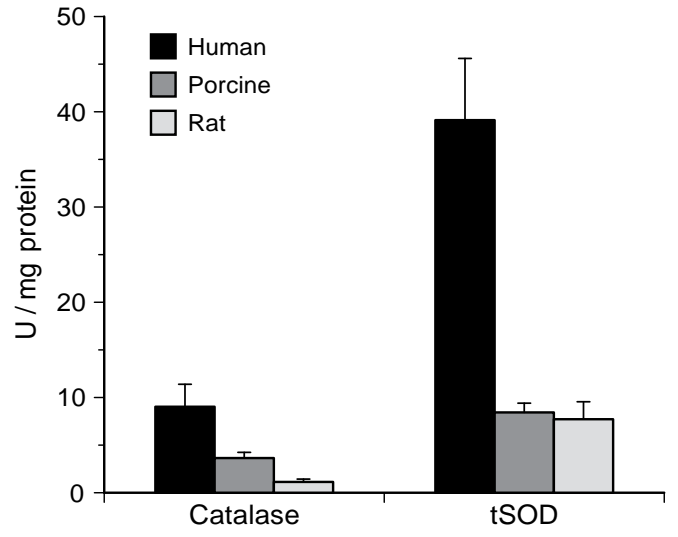

Fig. 1. Baseline catalase and total superoxide dismutase activities in human, porcine and rat islets. Results were obtained from triplicate samples taken from individual pancreas (human: $n=3$; porcine: $n=6$; rat: $n=5$ ). Mean \pm SEM from pooled data. Statistical significance was: $p=0.021$ human vs porcine, $p=0.01$ human vs rat, $p=0.04$ porcine vs rat (Catalase) and $p=0.001$ human vs porcine, $p=0.001$ human vs rat, $p=\mathrm{NS}$ porcine vs rat (tSOD)

$\mathrm{p}=0.04$ vs porcine). As another key scavenging enzyme that has not been explored previously in porcine islets, superoxide dismutase was also measured in our samples. Again, total superoxide dismutase activities exhibited an inter-species difference, with a four to fivefold higher level in human islets (39.1 $\pm 6.5 \mathrm{U} / \mathrm{mg}$, range 32.6-45.6, CV 23.5\%) than in porcine $(8.6 \pm 0.9 \mathrm{U} / \mathrm{mg}$, range 5.7-11.1, CV $24.7 \%, p=0.001$ vs human) and rat islets $(7.7 \pm 1.9$ $\mathrm{U} / \mathrm{mg}$, range $5.8-9.7$, CV 36.1\%, $p=0.001$ vs human and $p=$ NS vs porcine) (Fig. 1). Human islet SOD activity was predominantly MnSOD $(69.1 \pm 4.2 \%)$, as opposed to porcine islets which expressed more $\mathrm{Cu}$ ZnSOD $(74.5 \pm 8.7 \%)$. As expected, enzymatic contents of rat insulinoma cell line INS-1 did not significantly differ from those of primary rat islets, for catalase $(1.0 \pm 0.1 \mathrm{U} / \mathrm{mg}$, range $0.6-1.5$, CV $31.3 \%)$, total SOD $(8.7 \pm 0.4 \mathrm{U} / \mathrm{mg}$, range $6.7-10.7, \mathrm{CV} 15.6 \%)$, and proportion of CuZnSOD (63.9 $\pm 2.5 \%)$.

Efficiency of transfection. Following adenovirus-mediated catalase gene transfer, enzyme activity increased 2.5- to 7-fold in human islets (baseline $11.50 \pm 1.04 \mathrm{U} / \mathrm{mg}$; transfected $28.90 \pm 1.40 \mathrm{U} / \mathrm{mg}$ ), porcine islets (baseline $3.13 \pm 0.34 \mathrm{U} / \mathrm{mg}$; transfected $12.60 \pm 1.25 \mathrm{U} / \mathrm{mg}$ ), rat islets (baseline $1.32 \pm 0.33 \mathrm{U} /$ $\mathrm{mg}$; transfected $4.06 \pm 0.57 \mathrm{U} / \mathrm{mg}$ ), and INS-1 cells (baseline $1.0 \pm 0.1 \mathrm{U} / \mathrm{mg}$; transfected $7.0 \pm 0.6 \mathrm{U} / \mathrm{mg}$ ) when measured $48 \mathrm{~h}$ after transfer, using an MOI of 25 pfu per islet cell $(p<0.01$ control vs AdCAT) (Fig.2). Efficiency of transfection was slightly higher in dispersed single rat cells $(4.17 \pm 0.61 \mathrm{U} / \mathrm{mg})$ than in intact rat islets, therefore, dispersed rat islet cells were subsequently used in this study. This increase was dose-dependent, as judged from data obtained $48 \mathrm{~h}$ after gene transfer from human islets transfected 


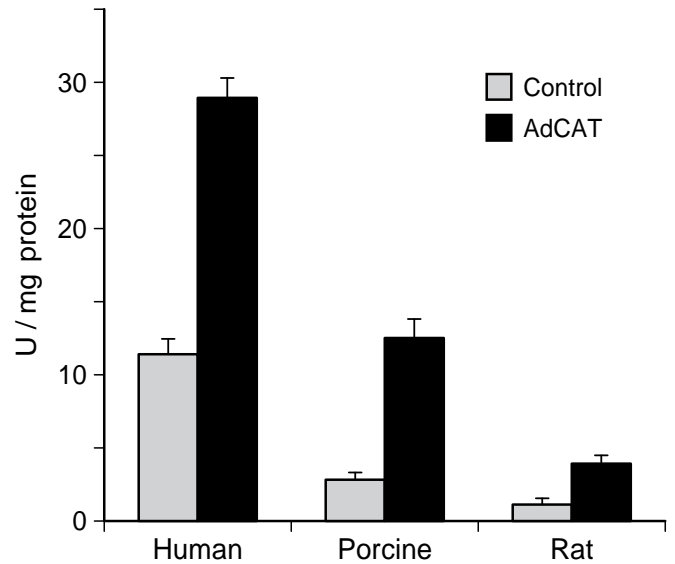

Fig. 2. Catalase activity in human, porcine and rat islets $48 \mathrm{~h}$ following gene transfer using AdCAT at MOI of 25. Results were obtained from triplicate samples taken from different individual pancreases (human: $n=3$; porcine: $n=6$; rat: $n=5$ ). Mean \pm SEM from pooled data. In all three species, catalase activities achieved by AdCAT transfection were higher (2.5-4-fold) than in control islets $(p<0.01$ control vs AdCAT)

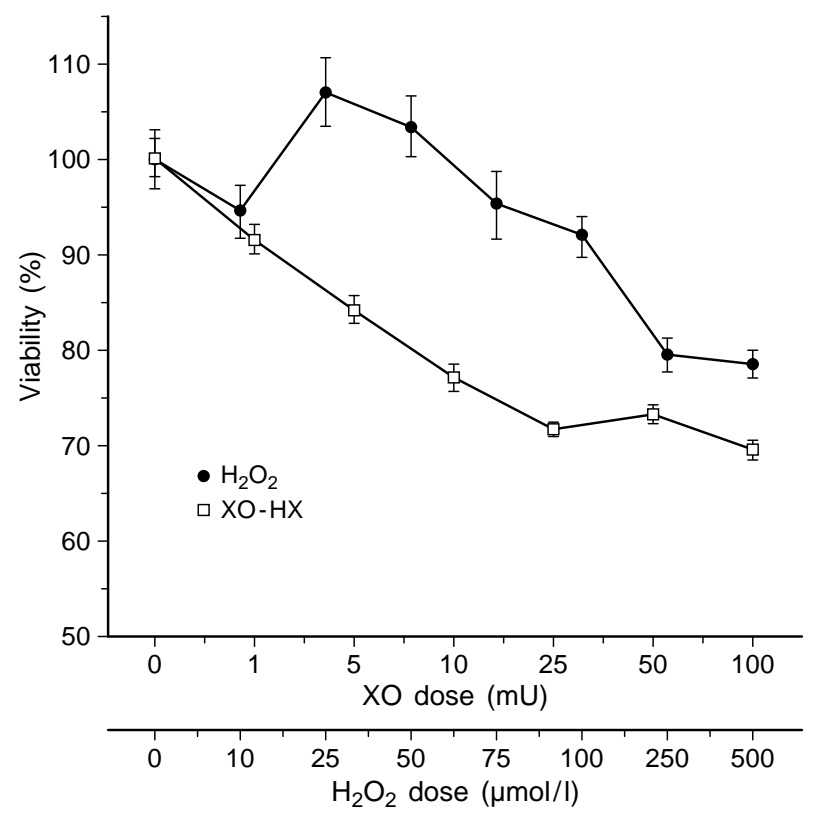

Fig. 3. Viability of human islets as assessed by WST-1 assay, following oxidative stress induced by increasing doses of hydrogen peroxide or xanthine oxidase in the presence of $0.5 \mathrm{mmol} / \mathrm{l}$ hypoxanthine. The validity of the model was established from experiments repeated on three preparations of human islets, in sextuplate wells, showing consistent dose-dependency of stress. Results of a typical experiment are shown here

at different MOIs (MOI $0=11.5 \pm 1.0 ;$ MOI $10=14.2 \pm 0.7 ; \quad$ MOI 25: 28.9 $\pm 1.4 ; \quad$ MOI 50: $62.8 \pm 0.4 \mathrm{U} / \mathrm{mg}$ ). Catalase activity was monitored for 7 days in intact porcine islet culture and up to 13 days with dispersed rat islet cells and was found to be consistently above baseline levels (data not shown).
Establishment of the oxidative stress model. After exposure of human islets to increasing doses of $\mathrm{XO}$ in the presence of $0.5 \mathrm{mmol} / 1 \mathrm{HX}$, a dose-dependent cytotoxic effect was shown by WST-1 assay and confirmed by microscopic examination of islets. As shown in Figure 3, doses of XO of 1 to $100 \mathrm{mU}$ resulted in a cytotoxicity of 7 to $31 \%$ respectively. Similarly, $\mathrm{H}_{2} \mathrm{O}_{2}$ at doses of 75 to $500 \mu \mathrm{mol} / \mathrm{l}$ progressively decreased human islet viability with a cytotoxicity of 5 to $21 \%$ respectively (Fig. 3). Porcine islets were also vulnerable to $\mathrm{XO}$ in a dose-dependent fashion, however, a tendency towards a higher susceptibility was observed as doses of $\mathrm{XO}$ of 10, 25 and $50 \mathrm{mU}$ resulted in a cytotoxicity of 38,39 and $41 \%$, respectively. Hydrogen peroxide at a concentration of $100 \mu \mathrm{mol} / \mathrm{l}$ reduced porcine islet viability by $11 \%$. Rat islet cells were also more vulnerable than human islets to XOHX stress as an equivalent cytotoxicity appeared at lower concentrations of XO (\% cytotoxicity $23 \pm 0.4$ at $2.5 \mathrm{mU} ; 30 \pm 0.2$ at $5 \mathrm{mU} ; 31 \pm 0.1$ at $10 \mathrm{mU} ; 30 \pm 0.4$ at $15 \mathrm{mU})$. Although dose-dependency of stress was consistently observed, the absolute level of cytotoxicity varied between different batches of islets. Thus, xanthine oxidase at a dose of $25 \mathrm{mU}$ induced an average cytotoxicity of $32.5 \pm 4.5 \%$ on human islets with a CV of $19.6 \%$. On the other hand, the same stress on porcine islets resulted in an average cytotoxicity of $40.5 \pm 8.2 \%$ with a CV of $40.5 \%$.

Efficiency of catalase gene transfer on islet viability. Each experiment was conducted with a minimum of 6 wells per experimental group (control, AdCAT and AdNull - with or without stress) and were repeated with islets from different preparations (human: $n=4$; porcine: $n=6$; rat: $n=5$; INS-1: $n=3$ ). As illustrated in Table 1, Table 2 and Figure 4, adenovirus-driven catalase overexpression (MOI 25) reduced cytotoxicity induced by $25 \mathrm{mU}$ XO on human and porcine islets resulting in a protection of 26.1 and $21.2 \%$, respectively. A 35.4 and $57.9 \%$ protection was also observed in human and porcine islets against the cytotoxicity induced by $\mathrm{H}_{2} \mathrm{O}_{2}$ (Fig. 4). Cytotoxicity of increasing doses of $\mathrm{XO}$ on dispersed rat islet cells was also reduced, as shown in Figure 5, with protection ranging from $12.4-17.8 \%$. This protection involved beta cells within the islets, as suggested by data obtained with INS-1 cells, showing a $30.8 \%$ protection after a XO stress (Table 2 ).

Effects of catalase gene transfer on islet functionality. The endocrine function of human islets was tested by static incubations $72 \mathrm{~h}$ after the induction of oxidant stress. Control islets normally responded to a glucose-theophylline challenge (baseline insulin release $72 \pm 9$; stimulated $144 \pm 17 \mu \mathrm{U} \cdot \mathrm{h}^{-1} \cdot 100$ islets $\left.^{-1}\right)$. As expected, insulin release was dramatically reduced after a hypoxanthine-xanthine oxidase chal- 
Table 1. Effect of catalase gene transfer on human, porcine and rat islet viability

\begin{tabular}{|c|c|c|c|c|c|c|}
\hline & \multicolumn{3}{|c|}{ \% cytotoxicity $\mathrm{XOHX}^{\mathrm{a}}$} & \multicolumn{3}{|c|}{$\%$ cytotoxicity $\mathrm{H}_{2} \mathrm{O}_{2}{ }^{\mathrm{a}}$} \\
\hline & control & AdNull & $\mathrm{AdCAT}^{\mathrm{c}}$ & control & AdNull & AdCAT \\
\hline human & $37.0 \pm 0.6$ & $34.8 \pm 2.1$ & $26.2 \pm 2.4^{\mathrm{d}}$ & $34.7 \pm 2.4$ & $35.9 \pm 3.2$ & $21.8 \pm 1.6^{\mathrm{d}}$ \\
\hline porcine & $60.1 \pm 0.9$ & $61.5 \pm 1.3$ & $47.4 \pm 2.3^{\mathrm{d}}$ & $12.5 \pm 3.1$ & $9.2 \pm 1.7$ & $5.3 \pm 1.3^{\mathrm{d}}$ \\
\hline rat & $30.1 \pm 0.4$ & ND & $24.7 \pm 0.4^{\mathrm{d}}$ & ND & ND & ND \\
\hline INS-1 ${ }^{\mathrm{b}}$ & $36.0 \pm 1.2$ & $35.3 \pm 1.1$ & $25.0 \pm 3.2^{\mathrm{d}}$ & ND & ND & ND \\
\hline
\end{tabular}

${ }^{\text {a }}$ xanthine oxidase was used at $25 \mathrm{mU} / \mathrm{ml}$ with human and porcine islets, $15 \mathrm{mU}$ with rat islets, $10 \mathrm{mU}$ with INS-1 cells. Hypoxanthine was $0.5 \mathrm{~mol} / 1 . \mathrm{H}_{2} \mathrm{O}_{2}$ was used at $250 \mu \mathrm{mol} / \mathrm{l}$ with human islets and $100 \mu \mathrm{mol} / \mathrm{l}$ with porcine islets.

${ }^{\mathrm{b}}$ studies were performed on intact human and porcine islets (20 islets / well), whereas rat islets were dispersed in single cells $\left(4 \times 10^{5}\right.$ cells / well $)$, INS- 1 cells were plated at $3 \times 10^{4}$ cells / well.

c AdCAT was used at MOI 25, and islets and cells were cultured $48 \mathrm{~h}$ prior to stress.

Table 2. Effect of catalase gene transfer on human, porcine and rat islet viability

\begin{tabular}{lll}
\hline & $\%$ protection XOHX & \% protection $\mathrm{H}_{2} \mathrm{O}_{2}{ }^{\mathrm{a}}$ \\
\hline human $(n=4)$ & $26.1 \pm 6.1$ & $35.4 \pm 4.2$ \\
porcine $(n=6)$ & $21.2 \pm 9.8$ & $57.9 \pm 10.5$ \\
rat $(n=5)$ & $17.8 \pm 2.3$ & $\mathrm{ND}$ \\
INS-1 $(n=3)$ & $30.8 \pm 8.7$ & $\mathrm{ND}$ \\
\hline
\end{tabular}

${ }^{a}$ Protection rate was computed as $(\mathrm{C}-\mathrm{T} / \mathrm{C}) \times 100$, where $\mathrm{C}$ is cytotoxicity oberved in control islets and $\mathrm{T}$ is cytotoxicity measured in transfected islets. Data were pooled from different islet or cell preparations $(n)$

lenge (baseline: $19 \pm 2 \mu \mathrm{U}$; stimulated: $75 \pm 24 \mu \mathrm{U}$ ) (Fig. 6). AdCAT transfected islets, however, retained their responsiveness to glucose + theophylline even after being stressed by XO-HX (baseline: $88 \pm 14 \mu \mathrm{U}, p<0.05$ vs stressed control; stimulated: $267 \pm 18 \mu \mathrm{U}, p<0.05$ vs stressed control). In fact, unstressed transfected islets exhibited higher insulin secretory capacities (baseline $98 \pm 14 \mu \mathrm{U}, p=\mathrm{NS}$ vs control; stimulated $370 \pm 31 \mu \mathrm{U}, p<0.05$ vs control) when compared with unstressed control islets.

\section{Discussion}

The results of our study demonstrate: 1) pancreatic islets from three different species (human, porcine and rat) express different levels of catalase activity; 2) the three categories of islets are susceptible to lysis by oxidant stress; 3) adenovirus-mediated catalase gene transfer can significantly raise catalase in islets for prolonged periods; 4) catalase gene transfer allows a partial reduction of islet susceptibility to oxidant stress and a preservation of insulin secretory capacities in vitro.

Previous studies had pointed out the major differences between humans and rodents in the susceptibility to beta-cell injury [12]. We established porcine is-
${ }^{\mathrm{d}}$ due to variability in cytotoxicity levels between batches of islets, this table shows data of typical experiments. Cytotoxicity levels were compared by analysis of variance and Scheffe's test between the 3 groups (control, AdNull, AdCAT). $P<0.05$ AdCAT vs control. AdNull and control did not differ significantly. Similar significant results were obtained when pooled cytotoxicity data from different pancreas were compared. ND: not determined

lets, a possible source for human transplants, also exhibit a much lower enzymatic activity of catalase and superoxide dismutase than human islets. Porcine islets, as human and rodent islets, are susceptible to lysis induced by reactive oxygen species generated by $\mathrm{XOHX}$ or $\mathrm{H}_{2} \mathrm{O}_{2}$. Interestingly, vulnerability to $\mathrm{XO}$ of rat islet cells, and to a lesser degree of porcine islets appeared higher than that of human islets, which could be related to the different catalase enzymatic activity that we observed between these species.

$\mathrm{H}_{2} \mathrm{O}_{2}$ is a major cytotoxic product of inflammatory cells. Xanthine oxidase is an endothelial enzyme known to generate reactive oxygen species (hydrogen peroxide and superoxide radical $\mathrm{O}_{2}^{-}$) when converting hypoxanthine to uric acid [26]. This enzyme may be particularly involved in tissue damage occurring after reperfusion/reoxygenation processes and can also be induced by tumour necrosis factor-alpha (TNF- $\alpha$ ) [27]. Previous studies have shown the cytotoxic role of this enzymatic system on rat pancreatic islet cells [28]. We now establish the dose-dependent cytotoxicity of $\mathrm{XO}$ on human and porcine islets. This could be relevant to islet transplantation, as XO may be activated by macrophages or hypoxia after graft implantation in the portal system. Thus, it is of particular interest to have a method that can reduce the deleterious effects of macrophage mediators that are implicated in islet graft primary non function [29-30] or in the destruction of microencapsulated islets [31].

The relative susceptibility of the different endocrine cell types in islets to oxidant stress and to catalase gene transfer was indirectly addressed in this study. Thus we observed that the rat beta-cell line INS-1 exhibited similar baseline catalase levels as primary rat islets, was susceptible to cytotoxicity induced by xanthine oxidase and was similarly protected against an oxidant stress by adenoviral-mediated catalase gene transfer. Recent studies using transgenic expression of superoxide dismutase targeted to islet beta cells confirmed the validity of this protective 


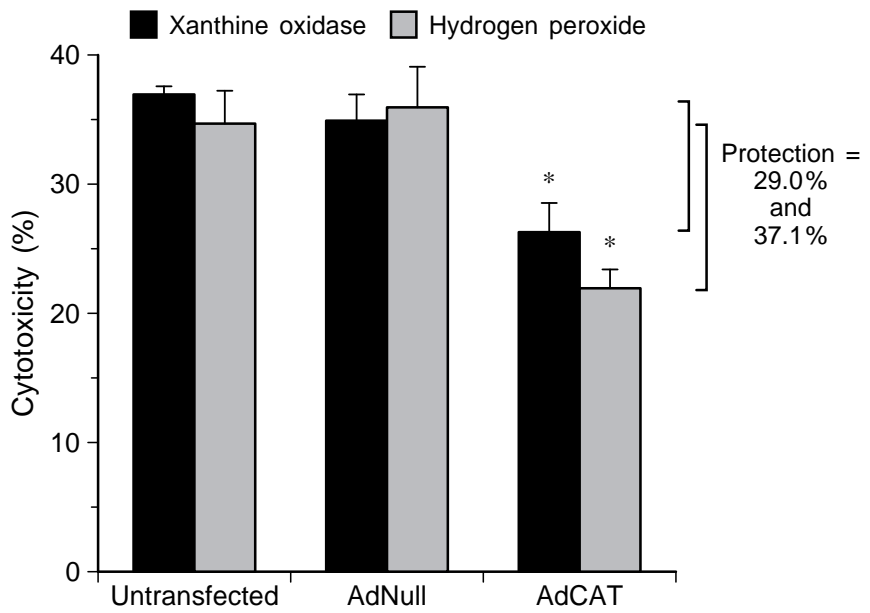

Fig.4. Effect of catalase gene transfer on human islet viability. AdCAT at MOI 25 reduces the cytotoxicity induced by xanthine oxidase $(25 \mathrm{mU}$, hypoxanthine $0.5 \mathrm{mmol} / \mathrm{l})$ or hydrogen peroxide $(250 \mu \mathrm{mol} / \mathrm{l})$. Each experiment was conducted with a minimum of six wells per experimental group (control, AdCAT and AdNull - with or without stress) and were repeated with islets from four different preparations. Data shown here are from a typical experiment. Cytotoxicity was compared between groups by analysis of variance followed by Scheffe's test (*: $p<0.05$ vs control). Protection rate was computed as $(\mathrm{C}-\mathrm{T} / \mathrm{C}) \times 100$, where $\mathrm{C}$ is cytotoxicity observed in control islets and $\mathrm{T}$ is cytotoxicity measured in transfected islets

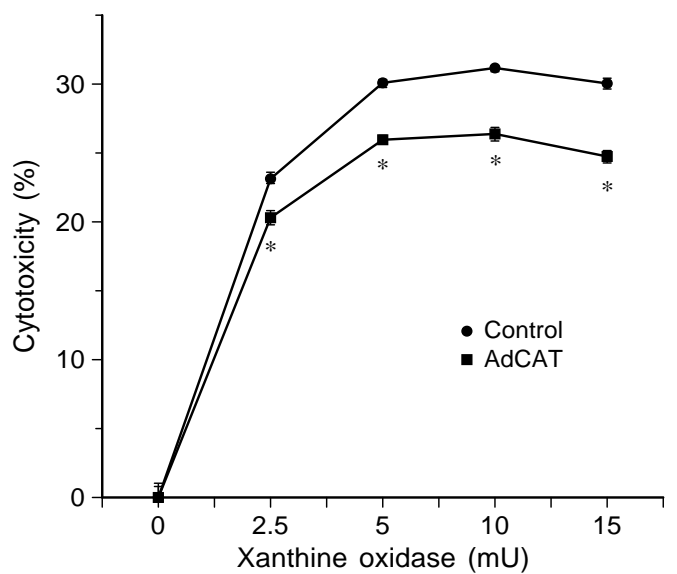

Fig. 5. Reduction of xanthine oxidase-induced cytotoxicity on dispersed rat islet cells by AdCAT. Islet cells were transfected at MOI 25, incubated at $5 \times 10^{4}$ cells per well for $48 \mathrm{~h}$, stressed by various doses of $\mathrm{XO}$ in the presence of $0.5 \mathrm{mmol} / \mathrm{HX}$, and assessed for viability by WST-1 assay $16 \mathrm{~h}$ later. Data show mean \pm SEM of six wells per experimental group. Results of a typical experiment are shown here and were repeated on five rat islet preparations. *: $p<0.05$ control vs transfected cells

approach [32], as well as recent data obtained with catalase gene transfer into insulinoma RINm5F cells [33].

The concept of protecting islets with antioxidant systems had already been proposed. Studies have been reported using the delivery of catalase enzyme

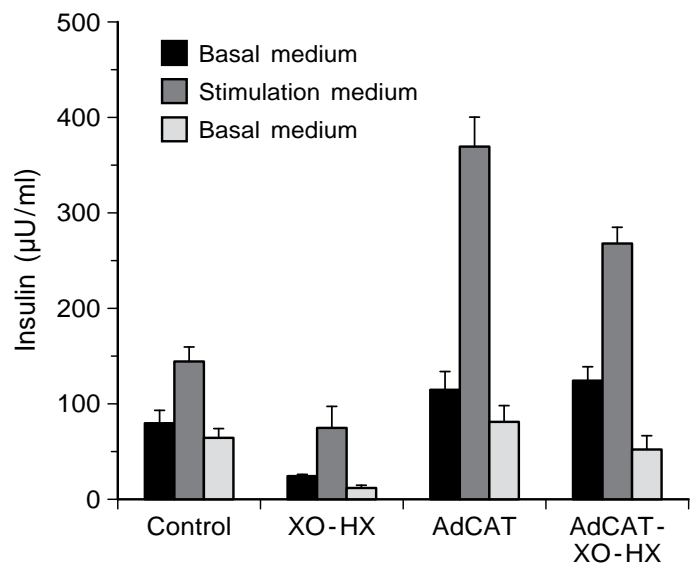

Fig. 6. AdCAT can prevent the reduction in basal- and stimulated-insulin release observed after a xanthine oxidase-hypoxanthine stress. Human islets were infected with AdCAT (MOI 25), exposed $48 \mathrm{~h}$ later to oxidant stress (XO-HX), and were successively incubated in basal (glucose $3.3 \mathrm{mmol} / \mathrm{l}$ ), stimulation (glucose $27.5 \mathrm{mmol} / \mathrm{l}$ + theophylline $10 \mathrm{mmol} / \mathrm{l}$ ), then basal medium again for three periods, $72 \mathrm{~h}$ after stress. A typical static incubation is shown here and was repeated on three human islet preparations

via liposomes in combination with SOD and glutathione peroxidase which showed beneficial effects on $\mathrm{H}_{2} \mathrm{O}_{2}$-induced cytotoxicity on rat islets in vitro [34]. Delivery of SOD or catalase complexed with polyethylene-glycol was shown to reduce the severity of insulitis in the NOD mouse model [6]. Our study extends this concept to human and porcine islets. Approaches thus far reported, used pharmacological agents [34] or physical treatment such as heat shock [35]. Although these can prove valid in vitro, the practicability and efficiency in vivo in an islet transplant setting are questionable. Therefore, the use of a powerful gene transfer vector might be more relevant and this is the first study reporting on such an approach. With the adenoviral vector, we were able to raise islet catalase activity for a minimum of 13 days. This period may be critical for protecting transplanted islets against inflammatory mediators released by macrophages and for promoting islet engraftment. Noteworthy, short term procedures used in the clinical transplant setting and believed to reduce primary non function, such as peritransplant optimal blood glucose control or pentoxifyllin, did improve clinical islet transplantation outcome in humans. Thus, the current gene transfer procedure, despite possible limited time expression, could positively influence islet transplantation results.

Inflammatory cytokines are candidate mediators of islet beta-cell destruction in the course of insulindependent diabetes mellitus as well as during islet rejection following transplantation [36-37]. These cytokines, IL- $1 \beta$, TNF- $\alpha$ and interferon gamma (IFN- $\gamma$ ) individually or in combination, are known to be cytotoxic to islet beta cells in vitro. Interestingly, rodent 
cells are more susceptible to these cytotoxic effects than human islet beta cells. There is strong evidence for a role of reactive oxygen species as intermediate mediators for cytokine-induced cytotoxicity [38-40], although some contradictory data exist showing no effect of liposomal delivery of CAT, SOD or GPX on cytokine-induced cytotoxicity in rat islets [34, 41], as well as no effect on NO-induced cytotoxicity [42]. Some authors have suggested that this inefficiency of superoxide dismutase or catalase could be attributed to their inability to penetrate islet cells [41]. Therefore the protective role of catalase from cytokine-induced cytotoxicity is currently under investigation in our laboratory, using our gene transfer strategy. In addition several investigators are now reporting on the role of protective genes that are expressed during accommodation of vascularized xenografts and prevent upregulation of proinflammatory genes such as cytokines [43]. Some of these protective genes, namely heme- oxygenase and bcl-2, are known for their antioxidant properties.

Although significant, the protection conferred to islets by catalase gene transfer was partial and much lower than that described with endothelial cells using the same vector [21]. The reason is unclear, as catalase activities at baseline and after transfection at the same MOI were very similar in both endothelium and islets. An heterogenous distribution of the transgene inside the islet may confer a protection to the peripheral islet cells only, while central core islet cells remain unaffected [16]. Protection of dispersed single rat islet cells, however, was not higher. Our study with rat cells used higher concentrations of hypoxanthine than that reported by other groups [35], suggesting that our strategy could be more relevant with a lower oxidant stress. In addition, it was reported that SOD and catalase could diminish the reduction of nitroblue tetrazolium to monoformazan [44], which could lead to an underestimation of the beneficial effect of AdCAT when viability was assessed by WST-1 assay. This also could explain that, while viability data established with WST-1 assay showed only partial improvement, functionality data showed that insulin release was almost totally preserved by AdCAT treatment. Noteworthy, the stimulation index (stimulated/basal insulin release) did not differ between control unstressed and stressed islets, suggesting that XOHX induced a loss of islets without disturbing the functionality of surviving islets. The increase in basal and stimulated insulin secretion in AdCAT transfected islets is unclear and could be related to modification in mitochondrial metabolism induced by catalase overexpression, as mitochondrial activation can trigger insulin secretion [45]. Finally, other defense mechanisms, such as SOD or gluthatione peroxidase, could prove useful, in combination with catalase, for the removal of reactive oxygen species. Indeed, we observed that the reduction of SOD activity in porcine islets compared with human islets was more pronounced than the reduction of catalase activity. It has recently been reported that targeted transgenic expression of $\mathrm{CuZnSOD}$ to islets could protect them against oxidant stress [32]. The effects of a double islet transfection with AdCAT and Ad$\mathrm{CuZnSOD}$ are currently under investigation.

Overall our data validate the concept of modulation of oxidant injury on islets through appropriate gene transfer and suggest that this method could be used as an adjuvant therapy to improve the outcome of islet or beta-cell transplantation. Our study also shows that investigations on islet defense mechanisms are relevant in the porcine model as well. It facilitates further investigations using scavenging enzyme gene transfer, aiming at reducing the adverse effects of non specific inflammation on islet engraftment and function in the in vivo transplant setting.

Acknowledgements. We thank Mrs Monique Bayle for doing insulin radioimmunassay, Philippe Prevost, Eric Rolland and Eliane Rossini for technical assistance. This work was supported by grants from Fondation de l'Avenir, Région Rhône-Alpes and Alfediam.

\section{References}

1. Mandrup-Poulsen T, Corbett JA, McDaniel ML, Nerup J (1993) What are the types and cellular sources of free radicals in the pathogenesis of Type I (insulin-dependent) diabetes mellitus? Diabetologia 36: 470-473

2. Corbett JA, Sweetland MA, Wang JL, Lancaster JR Jr, McDaniel ML (1993) Nitric oxide mediates cytokine-induced inhibition of insulin secretion by human islets of Langerhans. Proc Natl Acad Sci USA 90: 1731-1735

3. Eizirik DL, Flodström M, Karlsen AE, Welsh N (1996) The harmony of the spheres: inducible nitric oxide synthase and related genes in pancreatic beta cells. Diabetologia 39: 875-890

4. Papaccio G, Frascatore S, Pisanti FA, Latronico MV, Linn $\mathrm{T}$ (1995) Superoxide dismutase in the nonobese diabetic (NOD) mouse: a dynamic time-course study. Life Sci 56: 2223-2228

5. Suarez-Pinzon WL, Szabó C, Rabinovitch A (1997) Development of autoimmune diabetes in NOD mice is associated with the formation of peroxynitrite in pancreatic islet beta cells. Diabetes 46: 907-911

6. Horio F, Fukuda M, Katoh H et al. (1997) Reactive oxygen intermediates in autoimmune islet cell destruction of the NOD mouse induced by peritoneal exudate cells (rich in macrophages) but not T cells. Diabetologia 37: 22-31

7. Brenner HH, Burkart V, Rothe H, Kolb H (1993) Oxygen radical production is increased in macrophages from diabetes prone BB rats. Autoimmunity 15: 93-98

8. Xenos ES, Stevens RB, Sutherland DE et al. (1994) The role of nitric oxide in IL- $\beta$-mediated dysfunction of rodent islets of Langerhans. Implications for the function of intrahepatic islet grafts. Transplantation 57: 1208-1212

9. Grankvist K, Marklund SL, Täljedal IB (1981) CuZn-superoxide dismutase, Mn-superoxide dismutase, catalase and glutathione peroxidase in pancreatic islets and other tissues in the mouse. Biochem J 199: 393-398 
10. Lenzen S, Drinkgern J, Tiedge M (1996) Low antioxidant enzyme gene expression in pancreatic islets compared with various other mouse tissues. Free Radic Biol Med 20: 463-466

11. Welsh N, Margulis B, Borg LA et al. (1995) Differences in the expression of heat-shock proteins and antioxidant enzymes between human and rodent pancreatic islets: implications for the pathogenesis of insulin-dependent diabetes mellitus. Mol Med 1: 806-820

12. Eizirik DL, Pipeleers DG, Ling Z, Welsh N, Hellerstrom C, Andersson A (1994) Major species differences between humans and rodents in the susceptibility to pancreatic betacell injury. Proc Natl Acad Sci USA 91: 9253-9256

13. Sumoski W, Baquerizo H, Rabinovitch A (1989) Oxygen free radical scavengers protect rat islet cells from damage by cytokines. Diabetologia 32: 792-796

14. Kubisch HM, Wang J, Luche R et al. (1994) Transgenic copper/zinc superoxide dismutase modulates susceptibility to Type I diabetes. Proc Natl Acad Sci USA 91: 9956-9959

15. Csete ME, Benhamou PY, Drazan KE et al. (1995) Efficient gene transfer to pancreatic islets mediated by adenoviral vectors. Transplantation 59: 263-268

16. Benhamou PY, Mullen Y, Shaked A, Bahmiller D, Csete ME (1996) Decreased alloreactivity to human islets secreting recombinant viral interleukin 10 . Transplantation 62 : 1306-1312

17. Kerr-Conte J, Pattou F, Xia Y, Proye C, Lefebvre J (1994) Simple dithizone-stained multilayer test for selection of density gradient before human islet mass purification. Transplant Proc 26: 4013-4015

18. Peakman M, McNab GL, Heaton ND, Tan KC, Vergani D (1994) Development of techniques for obtaining monodispersed human islet cells. Transplantation 57: 384-393

19. Holmes MA, Clayton HA, Chadwick DR, Bell PRF, London NJM, James RFL (1995) Functional studies of rat, porcine and human pancreatic islets cultured in ten commercially available media. Transplantation 60: 854-860

20. Asfari M, Janjic D, Meda P, Li G, Halban PA, Wollheim CB (1992) Establishment of 2-mercaptoethanol-dependent differentiated insulin-secreting cell lines. Endocrinology 130: $167-178$

21. Erzurum SC, Lemarchand P, Rosenfeld MA, Yoo JH, Crystal RG (1993) Protection of human endothelial cells from oxidant injury by adenovirus-mediated transfer of the human catalase cDNA. Nucleic Acids Res 21: 1607-1612

22. Lafont A, Loirand G, Pacaud P, Vilde F, Lemarchand P, Escande D (1997) Identification of vasomotor dysfunction following adenoviral gene transfer in rabbit arteries. Hum Gene Ther 8: 1033-1040

23. Aebi H (1984) Catalase in vitro. Methods Enzymol 105: 121-126

24. Marklund S and Marklund G (1974) Involvement of the superoxide anion radical in the autooxidation of pyrogallol and a convenient assay of superoxide dismutase. Eur J Biochem 47: 469-474

25. Janjic D, Wollheim CB (1992) Islet cell metabolism is reflected by the MTT (tetrazolium) colorimetric assay. Diabetologia 35: 482-485

26. McCord JM (1985) Oxygen-derived free radicals in postischaemic tissue damage. N Engl J Med 312: 159-163

27. Ward PA (1991) Mechanisms of endothelial cell killing by $\mathrm{H}_{2} \mathrm{O}_{2}$ or products of activated neutrophils. Am J Med 91: 898-948

28. Burkart V, Koike T, Brenner HH, Kolb H (1992) Oxygen radicals generated by the enzyme xanthine oxidase lyse rat pancreatic islet cells in vitro. Diabetologia 35: 1028-1034
29. Kaufman DB, Gores PF, Field MJ et al. (1994) Effect of 15deoxyspergualin on immediate function and long-term survival of transplanted islets in murine recipients of a marginal islet mass. Diabetes 43: 778-783

30. Ueki M, Yasunami Y, Motoyama K, Funakoshi A, Ikeda S, Tanaka M (1995) The amelioration of hyperglycemia in streptozotocin-induced diabetic rats after the intraportal transplantation of an insufficient number of islets by nicotinamide treatment. Transplantation 60: 313-317

31. Cole DR, Waterfall M, McIntyre M, Baird JD (1992) Microencapsulated islet grafts in the $\mathrm{BB} / \mathrm{E}$ rat: a possible role for cytokines in graft failure. Diabetologia 35: 231-237

32. Kubisch HM, Wang J, Bray TM, Phillips JP (1997) Targeted overexpression of $\mathrm{Cu} / \mathrm{Zn}$ superoxide dismutase protects pancreatic $\beta$-cells against oxidative stress. Diabetes 46: $1563-1566$

33. Tiedge M, Lortz S, Drinkgern J, Lenzen S (1997) Relation between antioxidant enzyme gene expression and antioxidative defense status of insulin-producing cells. Diabetes 46: $1733-1742$

34. Welsh N, Margulis B, Bendtzen K, Sandler S (1994) Liposomal delivery of antioxidant enzymes protects against hydrogen peroxide- but not interleukin-1 beta-induced inhibition of glucose metabolism in rat pancreatic islets. $\mathrm{J}$ Endocrinol 143: 151-156

35. Bellmann K, Wenz A, Radons J, Burkart V, Kleemann R, Kolb H (1995) Heat shock induces resistance in rat pancreatic islet cells against nitric oxide, oxygen radicals and streptozotocin toxicity in vitro. J Clin Invest 95: 2840-2845

36. Rabinovitch A, Sumoski W, Rajotte RV, Warnock GL (1990) Cytotoxic effects of cytokines on human pancreatic islet cells in monolayer culture. J Clin Endocrinol Metab 71: 152-156

37. Soldevila G, Buscema M, Doshi M, James RF, Bottazzo GF, Pujol-Borrell R (1991) Cytotoxic effect of IFN-gamma plus TNF-alpha on human islet cells. J Autoimmun 4: 291-306

38. Andersen HU, Jorgensen KH, Egeberg J, Mandrup-Poulsen T, Nerup J (1994) Nicotinamide prevents interleukin-1 effects on accumulated insulin release and nitric oxide production in rat islets of Langerhans. Diabetes 43: 770-777

39. Borg LA, Cagliero E, Sandler S, Welsh N, Eizirik DL (1992) Interleukin-1 beta increases the activity of superoxide dismutase in rat pancreatic islets. Endocrinology 130: 2851-2857

40. Rabinovitch A, Suarez-Pinzon WL, Strynadka K, Lakey JRT, Rajotte RV (1996) Human pancreatic islet beta-cell destruction by cytokines involves oxygen free radicals and aldehyde production. J Clin Endocrinol Metab 81: 3197-3202

41. Yamada K, Inada C, Otabe S, Takane N, Hayashi H, Nonaka K (1993) Effects of free radical scavengers on cytokine actions on islet cells. Acta Endocrinol Copenh 128: 379-384

42. Burkart V, Kolb H (1993) Protection of islet cells from inflammatory cell death in vitro. Clin Exp Immunol 93: 273-278

43. Bach FH, Ferran C, Hechenleitner P et al. (1997) Accommodation of vascularized xenografts: expression of "protective genes" by donor endothelial cells in a host Th2 cytokine environment. Nat Med 3: 196-204

44. Baker JR, Zyzak DV, Thorpe SR, Baynes JW (1993) Mechanism of fructosamine assay: evidence against role of superoxide as intermediate in nitroblue tetrazolium reduction. Clin Chem 39: 2460-2465

45. Maechler P, Kennedy ED, Wollheim CB (1997) Mitochondrial activation directly triggers the secretion of insulin in rat pancreatic beta-cells. Diabetologia 40 [Suppl 1] A41 (abstract) 